\title{
The Neglected Mandate: Teaching Science as Part of Our Culture
}

\section{Citation}

Holton, Gerald. 2014. The Neglected Mandate: Teaching Science as Part of our Culture. Science \& Education 23 (9): 1875-1877. doi: 10.1007/s11191-013-9632-3

\section{Published Version}

10.1007/s11191-013-9632-3

\section{Permanent link}

http://nrs.harvard.edu/urn-3:HUL.InstRepos:37852654

\section{Terms of Use}

This article was downloaded from Harvard University's DASH repository, and is made available under the terms and conditions applicable to Open Access Policy Articles, as set forth at http:// nrs.harvard.edu/urn-3:HUL.InstRepos:dash.current.terms-of-use\#OAP

\section{Share Your Story}

The Harvard community has made this article openly available.

Please share how this access benefits you. Submit a story.

Accessibility 


\title{
The Neglected Mandate: Teaching Science as Part of our Culture ${ }^{1}$
}

\author{
Gerald Holton, Jefferson Physical Laboratory, Harvard University, Cambridge, MA, USA
}

I have been asked to introduce for your consideration a matter which is as urgent as the time given to me here is brief. I do so gladly, chiefly for two reasons:

One is that by experiment on a national and international scale it has been proven that teaching science with the inclusion of a measure of history and philosophy can be done, with success, even though with much labor.

The other reason is that at this way of improving science teaching is urgently needed just now. For let us be frank here: While we all know exemplary cases of fine science teaching, the results on average in this country are abysmal, by national and international comparisons. You all know the facts. For our profession as educators, this is a deeply sobering matter. Moreover, it is coming just at the time in history when, on many measures, the U.S. lags far behind those of many of our ambitious and wellorganized foreign opponents_-regarding the knowledge of science by students and the wider public, even regarding the respect for scientific reasoning and evidence-based facts. On this front, one may still say that ours is "A Nation at Risk."

Thus I earnestly believe that there is an urgent need to upgrade the teaching of science now. For the nation faces a challenge not very different from that, many decades ago, when the Soviet Union launched Sputnik. At that time we woke up, realizing how we had failed in many crucial ways, and seriously experimented with greatly improved science teaching. Many at this conference will have had some experience with those efforts.

I feel sure that from the results of the experiments which succeeded then there are valuable lessons for our own situation today. I have been invited to speak about one of them, in which I was and still am involved.

In a nutshell, it started with an approach to me from the National Science Foundation. The Foundation had supported a large-scale introductory physics course (Physical Science Study Committee) developed by distinguished physicists at MIT. It was imaginative and successful; but the Foundation was concerned that despite its excellence it was reaching a relatively small proportion of high school students in the US, of the order of $4 \%$. Therefore the Foundation asked me to help initiate a second curriculum development in physical science, one designed to reach a larger portion of the student body. I agreed, little knowing how much work this would involve.

From the beginning, I decided that this new course, based at Harvard and called Project Physics, would be enriched by a measure of history and philosophy, thus would take a humanistic approachprecisely the kind to which much of this conference is dedicated. I based my decision in part on the hunch that more beginning students would come to take this course, to learn not only that $F$ is equal to $m a$, but also that science is a fascinating part of human culture.

In addition, I started the course on this path because that is how I understand science. Years before starting Project Physics I had published a text book incorporating the humanistic enrichment (it

1 Invited Lecture at the Conference on "How Can the History and Philosophy of Science Contribute to Contemporary US Science Education?” (Boston University, December 7, 2012) 
had the clumsy title Introduction to Concepts and Theories in Physical Science (Holton, 1952). The same spirit went into the new course, eventually the result of a six-year-long effort involving hundreds of high school teachers in the writing and national try-outs, many distinguished scientists, as well as historians and philosophers of science. Thanks to James Rutherford, the extraordinary co-head of Project Physics, all printed materials are now available free on the Internet. ${ }^{2}$

And here is what can be learned for our purpose from all this. During and after the development, a veritable flood of assessments of success or failure was made, including over a dozen of Ph.D. theses in Graduate Schools of Education. The net result was as good as we could have hoped for. About four times as many students selected our course compared to PSSC, far more girls, with more than 200,000 students taking our course at its peak in the USA, and uncounted others in about a dozen foreign adaptations, from Italy to Japan. And as one of the assessments showed, our students on average did as well as others on the demanding Regents Tests of the knowledge of physics, even though those tests were only of the old, strictly $F=m a$ variety. ${ }^{3}$

The squishy phrase "understanding of science” can mean many things, but above all it must, I insist, include knowledge of science, plus an acquaintance with how science is done, plus a view of science as part of the cultural development of humanity. In addition to the nuts and bolts of a given subject, an educator of young persons has the ethical imperative to try to convey a way of thinking and functioning, a view of the world in which science has its proper place. It must be part of some preparation for a long life in a society in which science and technology are predominant forces, for better or worse.

So if one of your skeptical colleagues, on hearing you might engage in such a plan in your science teaching, came to you, horrified about it all ("There is no time for such extras, we constantly have to squeeze in more of the DNA and E is mcsquared type of stuff”), you have an answer:

"The humanistic approach to science teaching has been tried, and it works. If I were to leave out what you regard as extras, I would be apt to teach dead science, and my students would know it. Instead, I shall take on the more difficult task that my sense of obligation to my students requires, and they will thank me for it."

\section{References}

Ahlgren, A. \& Walberg, H.J. (1973). Changing Attitudes Toward Science among Adolescents. Nature, 245, 187-190.

Rutherford, F.J., Holton, G., Watson, F.G. Project Physics Collection, on archive.org. http://archive.org/details/projectphysicscollection. Accessed 29 May 2013.

Holton, G. (1952). Introduction to Concepts and Theories in Physical Science, $1^{\text {st }}$ ed., Addison Wesley Publishing Co., Cambridge, MA.

Holton, G. (2003). The Project Physics Course, Then and Now. Science \& Education, 12(8), 779-786.

2 http://archive.org/details/projectphysicscollection

3 See Ahlgren and Walberg (1973) for an overview. See also Holton (2003). 